Ismayil J. Sadigov

Institute of Information Technology ANAS, Baku, Azerbaijan

ismayil.sadigov@gmail.com

DOI: 10.25045/jpit.v09.i1.05

\title{
MODIFIED FLESCH FORMULA FOR EVALUATING THE COMPLEXITY OF TEXTS IN AZERBAIJANI LANGUAGE
}

The article touches upon the issue of applying the Flesch reading ease formula for texts in English to texts in Azerbaijani language. To solve this problem, it describes a technique for adjusting the coefficients in a formula corresponding to parameters, such as the average sentence length in words and the average word length in syllables. Based on this methodology, identical texts in English and Azerbaijani languages (samples of works of art, academic (scientific) texts, individual sentences and their verbatim translations) are studied and, as a result, the coefficients of the Flesch formula for texts in Azerbaijani language are adjusted.

Keywords: text complexity, readability formulas, Flesch reading ease formula.

\section{Introduction}

Scientific research on the complexity of texts began in the late 19th century in the United States. In fact, the prominent Azerbaijani mentor Abbasgulu Agha Bakikhanov focused on this issue in the first half of the same century. In 1836, in his pedagogical work titled "Kitabi-Nasihat" (Teaching) he was complaining about the complexity of the language of the textbooks about education and training: "I have not seen a textbook written in easy language. Available books are so hard and complicated that children and even teachers themselves do not understand them; and sometimes the sentences are too long to master and understand" $[1,2]$.

Apparently, A.Bakikhanov associated the complexity of the texts with too long sentences and a large number of complicated words. Remarkably, in the 1920s, researchers in the United States have found ways to predict the complexity of the text using the difficulty of words and the length of sentences [3].

\section{The concept of "readability"}

The term "readability" is used to indicate the degree of complexity of the text and its degree of perception. The word "readability" is translated into Russian as "читабельность" and into Turkish as "okunabilirlik", whereas in the "English-Azerbaijani Dictionary" written by O.Turksevar-Musayev (Baku: "Qismet" publishing house, 2003, p. 1696), it is interpreted into Azerbaijani as "easily readable" and "easy to read". Unquestionably, none of these translations can be used as a term. However, the texts with the featured characteristics are more precise in the expression "readability", which will be hereafter used in this article.

What is readability? Readability makes some texts more readable than others. This concept is often confused with the concept of "legibility", which is related to the line, font, and textual layout. The Readability does not mean "readable", as it is related to the content of the text and is used in the meanings of "interesting to read" [2].

George Klare defines readability as "understandable, easily understood, or understood due to the writing style" [4]. This definition does not focus on the textual content, logical sequences and structure, but on the writing style. Gretchen Hargis and his colleagues at IBM also agree with the definition of "readability of words and sentences" i.e., readability is a sign of the clarity of the text [5].

SMOG readability formula developer G. Harry McLaughlin describes readability as "the extent, to which a certain text material is credible and convincing for a given class of people" [6]. This definition particularly emphasizes the relationship between the text and the class of readers with known characteristics such as readability, basic knowledge, and motivation.

Perhaps, Edgar Dale and Jeanne Chall offer the most comprehensive definition of readability: "readability" is the totality of all elements (including all interactions) that affect the success of the 
group of readers in the given section of the printed material. Success is the rate of the readers to understand the text, read it at an optimum speed, and consider it to be interesting" [7].

\section{Readability formulas}

Many mathematical models are built to evaluate readability, many of which are based on mathematical formulas. These readability formulas are also expressed as readability tests and readability metrics in scientific literature.

Readability formulas are mathematical formulas simply derived from regression analysis. This procedure finds the equation that expresses the relationship between the two variables. Thus, one of these variables shows the size of the complexity that people experience when reading the given text, while the other denotes the measure of the linguistic characteristics of that text [6].

It should be noted that from 1920 to 1980, more than 200 readability formulas were developed for English texts, nonetheless, not all of them were successful. The following formulas are widely used [8]:

- Flesch Reading Ease Formula;

- Flesch-Kincaid Grade Level Formula;

- Fry Readability Formula;

- Gannning Fog Index;

- Dale-Chall Readability Formula;

- SMOG formula;

- Spache Readability Formula;

- Powers-Sumner-Kearl Readability Formula;

- FORCAST formula.

Note that the readability formulas are not the only quality indicator for the perception of text. The perception of text and understanding the material is affected by the structure of the sentences, the number of words per page, the presence of illustrations, cross references, the number of new words per page, the number of abstract words, and so forth. The readability assessment formulas do not evaluate the subtlety of the author's style, however they distinguish a simple clear text from a hard one.

\section{Key variables used for readability evaluation}

What are the characteristics of the text that affect its complexity? In other words, what factors should be considered to evaluate the complexity of the text?

The principle of identifying the complexity factors is simple: some simple texts and some other texts composed of several texts are given. These texts are compared to individual indicators, such as logical structure, topic, length of sentences, and other parameters. If the characteristic value changes from easy texts to hard ones, this characteristic is one of the complexity factors of the text. For example, comparison of simple and hard texts shows that the hard texts contain more unknown words and long sentences. Hence, the familiarity of words and the length of sentences depend on the complexity of the text [2].

Overall, researchers define 17 parameters affecting the complexity of the text most (Table 1) [2, 3]. 
Parameters affecting the complexity of the text

\begin{tabular}{|l|l|}
\hline № & \multicolumn{1}{|c|}{ Names of Parameters } \\
\hline 1. & Average sentence length in words \\
\hline 2. & Percentage of "easy" words \\
\hline 3. & Number of words not known to 90\% of sixth-grade students \\
\hline 4. & Number of "easy" words \\
\hline 5. & Number of different "hard” words \\
\hline 6. & Minimum syllabic sentence length \\
\hline 7. & Number of explicit sentences \\
\hline 8. & Number of first, second, and third-person pronouns \\
\hline 9. & Maximum syllabic sentence length \\
\hline 10. & Average sentence length in syllables \\
\hline 11. & Percentage of monosyllables \\
\hline 12. & Number of sentences per paragraph \\
\hline 13. & Percentage of different words not known to 90\% of sixth-grade students \\
\hline 14. & Number of simple sentences \\
\hline 15. & Percentage of different words \\
\hline 16. & Percentage of polysyllables \\
\hline 17. & Number of prepositional phrases \\
\hline
\end{tabular}

Undoubtedly, other necessary indicators are also available for calculating some of these 17 factors (Table 2).

Other variables used for readability formulas

\begin{tabular}{|c|l|}
\hline № & \multicolumn{1}{|c|}{ Names of Parameters } \\
\hline 1. & Number of sentences in the text \\
\hline 2. & Number of words in the text \\
\hline 3. & Number of "long" words in the text \\
\hline 4. & Number of monosyllabic words in the text \\
\hline 5. & Number of syllables \\
\hline 6. & Number of symbols in words of the text \\
\hline 7. & Number of symbols in the text \\
\hline 8. & Percentage of hard (difficult) sentences \\
\hline 9. & Average word length in syllables \\
\hline 10. & Average word length in symbols \\
\hline
\end{tabular}

\section{Flesch readability formula}

Each language has its own syntax, i.e. word and sentence structure. In other words, the values of these parameters are not the same for different languages. Thus, for example, the average length of words in English is shorter than in Azerbaijani or Russian. Moreover, the number of syllables in different languages is calculated differently: in most languages, the number of syllables is determined by the number of vowels, while in some languages it depends on the pronunciation. For example, the English word "analyze" consists of three syllables, while the word "analyses" of four syllables. Therefore, applying the readability formula developed for the texts of a language to another text in different language can generate incorrect results. More precisely, for the application of the readability formula, which is developed in accordance with the English syntax, to the texts in the Azerbaijani, the coefficients of this formula should be modified. 
In this article, one of these formulas, namely the Flesch readability formula is adapted for the Azerbaijani texts.

Flesch Reading Ease Formula uses two variables - sentence length in the text and the number of syllables of the word:

$$
\mathrm{K}=206.835-(1.015 \times \mathrm{S})-(84.6 \times \mathrm{W}),
$$

where $K$ is an indicator of the complexity (readability) of the text, $S$ - average sentence length (correlation of the number of words to the number of sentences), and $W$ - average number of syllables in the word (correlation of the number of syllables to the number of words).

For the easy application of the formula, this article offers the following method: 100 words are taken from any text; the average length of the sentences in the middle, and the average number of words out of these hundred words are calculated. The value of the readability may vary within 100 (very easy text) and 0 (very hard text) (Table 3).

Table 3

Flesch readability values

\begin{tabular}{|c|l|}
\hline Readability values (K) & \multicolumn{1}{|c|}{ Description } \\
\hline $0-29$ & very difficult \\
$30-49$ & difficult \\
$50-59$ & fairly difficult \\
$60-69$ & standard \\
$70-79$ & fairly easy \\
$80-89$ & easy \\
$90-100$ & very easy \\
\hline
\end{tabular}

Theoretically, the value of readability can be beyond the specified range. Thus, the highest readability score (easiest text) can be about 120: for example, each sentence of such text consists of two monosyllabic words. The readability score does not have a theoretically low limit (the lowest value), since it can be reduced to a minimum by adding arbitrary number of multisyllabic words to the text.

It should be emphasized that this formula was obtained for experimental texts in English. However, unlike English, the Azerbaijani is an agglutinative language from the morphological point of view, and the average sentence length is less than that of the English, while the average word count is more. Thus, sometimes a word in the Azerbaijani is expressed through several words in English as a sentence; for example: "Evdəydim." ("I was at home"). Therefore, to apply the formula (1) to the Azerbaijani texts, the coefficients in this formula should be corrected.

According to the statistics of the words included into the "Explanatory Dictionary of the Azerbaijani language" [6], the average words length is about 3 syllables: 3.18\% - mono-syllabic, $18.29 \%$ - disyllabic, $30.19 \%$ - trisyllabic, $25.38 \%$ - four-syllable, $8.77 \%$ - five-syllable, $2.68 \%$ sixsyllable and $0.73 \%$ seven and more syllabic words (Figure 1 ).

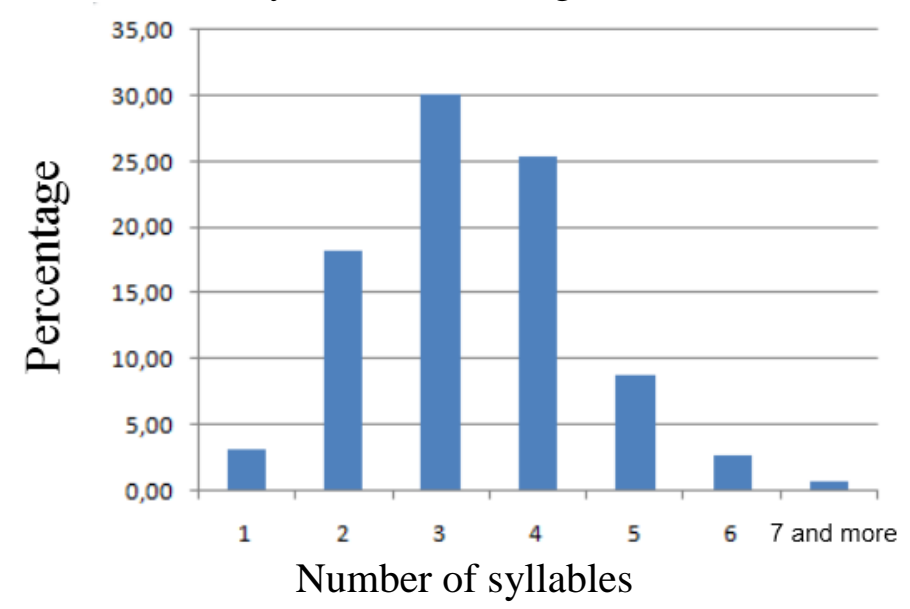

Figure 1. Syllabic percentage of words included into the "Explanatory

Dictionary of the Azerbaijani language" 
The value of the readability based on formula (1) is calculated for different values of the average sentence length and the average word length (Table 4).

Table 4

Dependence of the readability coefficient in Flesch formula on the number of words and syllables

\begin{tabular}{|c|c|c|c|c|c|c|c|c|c|}
\hline \multirow{12}{*}{ 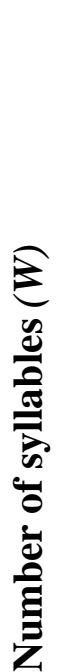 } & \multicolumn{9}{|c|}{ Number of words in a sentence $(S)$} \\
\hline & & 4 & 5 & 6 & 7 & 8 & 9 & 10 & 11 \\
\hline & 2.1 & 25 & 24 & 23 & 22 & 21 & 20 & 19 & 18 \\
\hline & 2.2 & 17 & 16 & 15 & 14 & 13 & 12 & 11 & 10 \\
\hline & 2.3 & 8 & 7 & 6 & 5 & 4 & 3 & 2 & 1 \\
\hline & 2.4 & 0 & -1 & -2 & -3 & -4 & -5 & -6 & -7 \\
\hline & 2.5 & -9 & -10 & -11 & -12 & -13 & -14 & -15 & -16 \\
\hline & 2.6 & -17 & -18 & -19 & -20 & -21 & -22 & -23 & -24 \\
\hline & 2.7 & -26 & -27 & -28 & -29 & -30 & -31 & -32 & -33 \\
\hline & 2.8 & -34 & -35 & -36 & -37 & -38 & -39 & -40 & -41 \\
\hline & 2.9 & -43 & -44 & -45 & -46 & -47 & -48 & -49 & -50 \\
\hline & 3 & -51 & -52 & -53 & -54 & -55 & -56 & -57 & -58 \\
\hline
\end{tabular}

As seen from the table, the value of the readability coefficient $(K)$ in Flesch formula is negative when the average syllable length is more than 2.3. In other words, the Flesch readability formula is not applicable for the Azerbaijani texts. To solve this problem, as mentioned above, the correlations in this formula should be corrected. In this regard, the average word lengths in Azerbaijani and English are first compared.

According to the research [8], the average length of 4,1977 English words in English-Russian dictionary edited by V.M.Muller is 2,977. "Explanatory Dictionary of Azerbaijani Language" [10] covering more than 48,000 words is used to calculate the average length of the Azerbaijani words.

Special software is developed to calculate the quantitative characteristics of the Azerbaijani texts (words). "Text analysis" software works with .doc or .docx files (figure 2). The results are shown in Table 5.

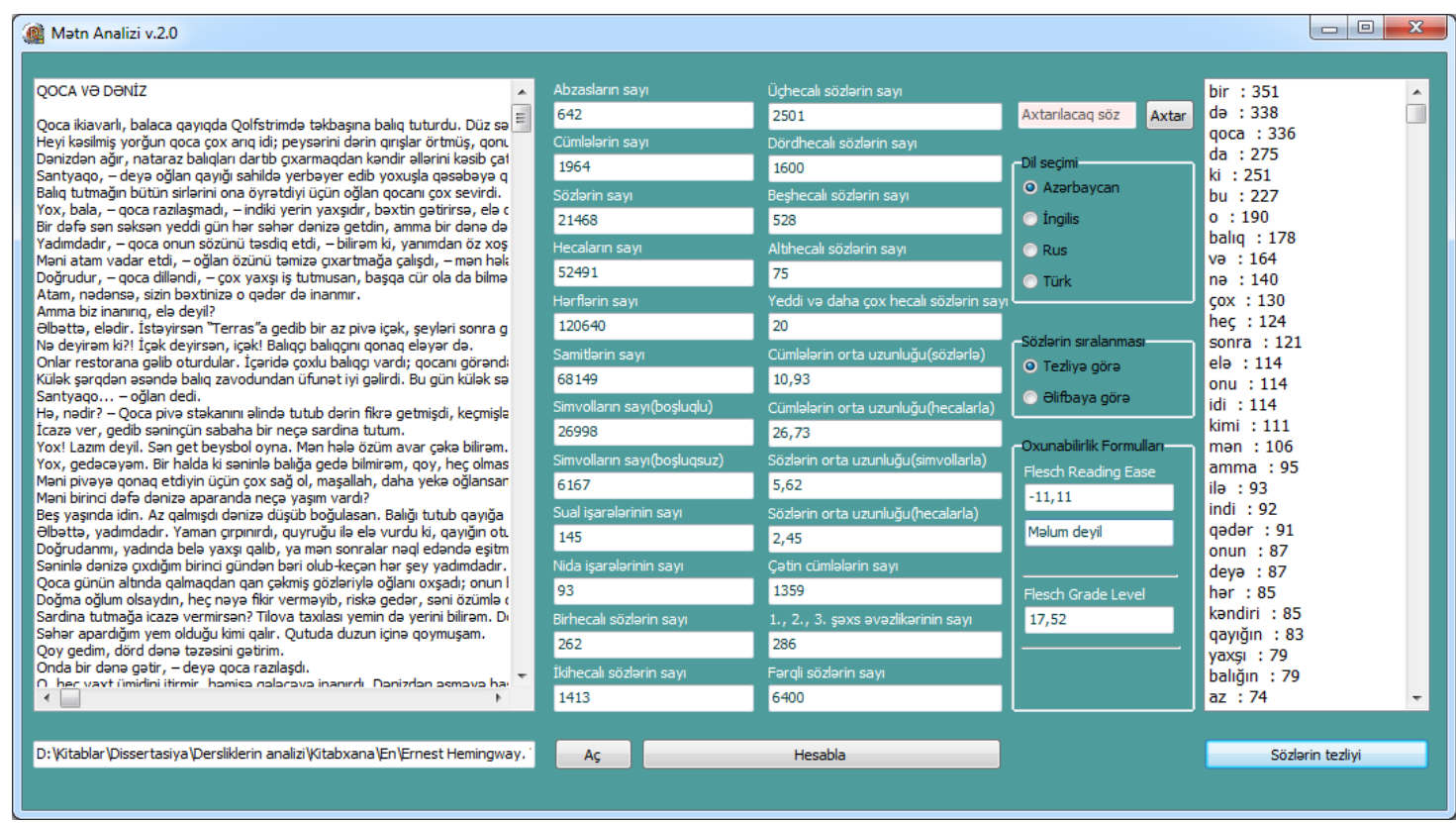

Figure 2. Screenshots of "Text Analysis" software 
Table 5

Comparative characteristics of the English and Azerbaijani words

\begin{tabular}{|l|c|c|c|c|c|}
\hline \multicolumn{1}{|c|}{ Name of the source } & $\begin{array}{c}\text { Number } \\
\text { of words }\end{array}$ & $\begin{array}{c}\text { Number } \\
\text { of } \\
\text { syllables }\end{array}$ & $\begin{array}{c}\text { Number of } \\
\text { syllables in } \\
\text { words }\end{array}$ & $\begin{array}{c}\text { Number of } \\
\text { consonants } \\
\text { in the } \\
\text { words }\end{array}$ & $\begin{array}{c}\text { Number of } \\
\text { multisyllabic } \\
\text { words }\end{array}$ \\
\hline English-Russian dictionary & 41977 & 124518 & $\mathbf{2 . 9 7}$ & 4.56 & 13495 \\
\hline $\begin{array}{l}\text { Explanatory dictionary of } \\
\text { Azerbaijani language }\end{array}$ & 48457 & 153443 & $\mathbf{3 . 1 7}$ & 4.72 & 32830 \\
\hline
\end{tabular}

Evidently, the average words length in English is 2.97 syllables, while in Azerbaijani this figure is equal to 3.17. Thus, the coefficient related to the average word length in Flesch formula should be corrected 1.07 times. Moreover, many words included into the "Explanatory Dictionary of the Azerbaijani language" multi-syllabic, i.e., three or more syllabic words make up $68 \%$ of the total, while this figure is $32 \%$ for English.

\section{Statistical analysis of different texts in the Azerbaijani language}

As mentioned above, since the Azerbaijani is an agglutinative language, the values calculated from the spelling dictionary related to words cannot be taken as a basis. More precise values are obtained based on the statistical analysis of different texts. In this study, it is proposed to use the following methodology: first, statistical indices of different texts in the Azerbaijani and their English originals, including the coefficient of the values of the needed indices of both languages are calculated. Then, it is necessary to calculate the average values for these indicators and to determine at what correlation the respective coefficients in the Flesch formula should be corrected. To ensure the high quality of the texts in both languages in terms of content and style, some English literary samples and their translations into Azerbaijani will be primarily used. However, as literary works and their translations depend largely on the style of the writer and interpreter, the academic texts of different contents and their English translations taken from the portal azerbaijan.az and the official website of the President of the Republic of Azerbaijan (www.president.az) will be analyzed similarly. In order to make the study more detailed, the statistical indices of the English texts and their Azerbaijani translations will also be taken into consideration.

The applications from http://countwordsworth.com and http://www.wordcalc.com will be used for the analysis of the English texts, and the "Text Analysis" for the analysis of the Azerbaijani texts, which is designed specifically for this research.

Electronic English literature is taken from pdbooks.ca/books/english/, www.fullbooks.com and http://etc.usf.edu/lit2go/. Their electronic Azerbaijani translations are taken from the publishing houses "Altun Book", "East-West", "Baku" and www.translit.az.

"Text Analysis" calculates the following quantitative characteristics of the texts:

- number of paragraphs, sentences, syllables, letters, consonants, characters, question marks, and exclamation marks;

- number of words with one, two, three, four, five, six, seven, and more syllables;

- average sentences length (by words), average sentences length (by syllables);

- average words length (by symbols), average words length (by syllables);

- number of pronouns of the first, second and third persons;

- number of distinct words.

In this case, the following facts are taken into consideration: 
1. The sequence of characters (letters, figures, special characters) that do not contain spaces and punctuation marks is taken as a word (e.g. readability, biography, UN, 1962).

2. The number of syllables in the words is determined by the number of vowels.

3. A sentence is a set of characters that start with capital letter and end with a dot, exclamation or question mark.

Table 6 illustrates the quantitative characteristics of the original texts of some works (or fragments) by Mark Twain, Jack London, Herbert Wales, Ernest Hemingway, John Galswarthy and other prominent representatives of the English literature and their Azerbaijani translations. As it is seen from this table, the length of words in English by syllables is shorter than the length of the words in Azerbaijani. Thus, the average length of words in English is $\bar{x}=1.27$ syllable (minimal length $-x_{\min }=1.15$, maximum length $-x_{\max }=1.36$ syllable, and variance $-\sigma^{2}=0.005$ ). The values of their Azerbaijani translations are as follows: average words length $-\bar{x}=2.45$ syllables, minimal words length $-x_{\min }=2.23$ syllables, maximal words length $-x_{\max }=2.58$, and variance $-\sigma^{2}=0.01$.

$$
\begin{gathered}
\text { Dispersion_words_length } h_{\text {eng }}=\frac{1}{n} \sum_{i=1}^{n}\left(x_{i}-\bar{x}\right)^{2}=0.005 . \\
\text { Dispersion_words_length } h_{a z e}=0.01 .
\end{gathered}
$$

The $8^{\text {th }}$ column of the table calculates the following ratio for each work:

$$
\frac{\text { Average number of words in sentence (English text) }}{\text { Average number of words in sentence (Azerbaijani translation) }}
$$

On the one hand, the number of words in a sentence is related to the syntactic features of the language, and to the style of the writer and translator on the other. Therefore, this figure significantly differs in separate literary works. As can be seen from the table, the variation by the number of words sentence is between 0.62 and 0.88, hence, English sentences are approximately 0.72 times longer than the Azerbaijani sentences, while the variance and standard deviation are 0.0059 and 0.0768 , respectively:

$$
\begin{gathered}
\text { Range of deviation: } R=x_{\max }-x_{\min }=0.88-0.62=0.26 \\
\text { Sample mean: } \bar{x}=\frac{1}{n} \sum_{i=1}^{n} x_{i}=0.72 \\
\text { Variance: } \sigma^{2}=\frac{1}{n} \sum_{i=1}^{n}\left(x_{i}-\bar{x}\right)^{2}=0.0059 \\
\text { Standard deviation: } \sigma=0.0768
\end{gathered}
$$

The $9^{\text {th }}$ column of the table calculates the following ratio for each work:

$\frac{\text { Average number of syllables in words (English text) }}{\text { Average number of syllables in words (Azerbaijani translation) }}$

These numerical values indicate that the average number of syllables in English words is 1.93 times smaller than the respective indicators in the Azerbaijani texts. According to these values, the variation ranges from 1.82 to 2.04 , whereas the variance and standard deviation are 0.0076 and 0.0872 , respectively.

These texts, which are statically analyzed, are fictions. Next, several examples of academic (scientific) works are analyzed in the same way (table $6 *$ ). 
Table 6

Comparison of the quantitative characteristics of the identical literary samples in English and

Azerbaijani

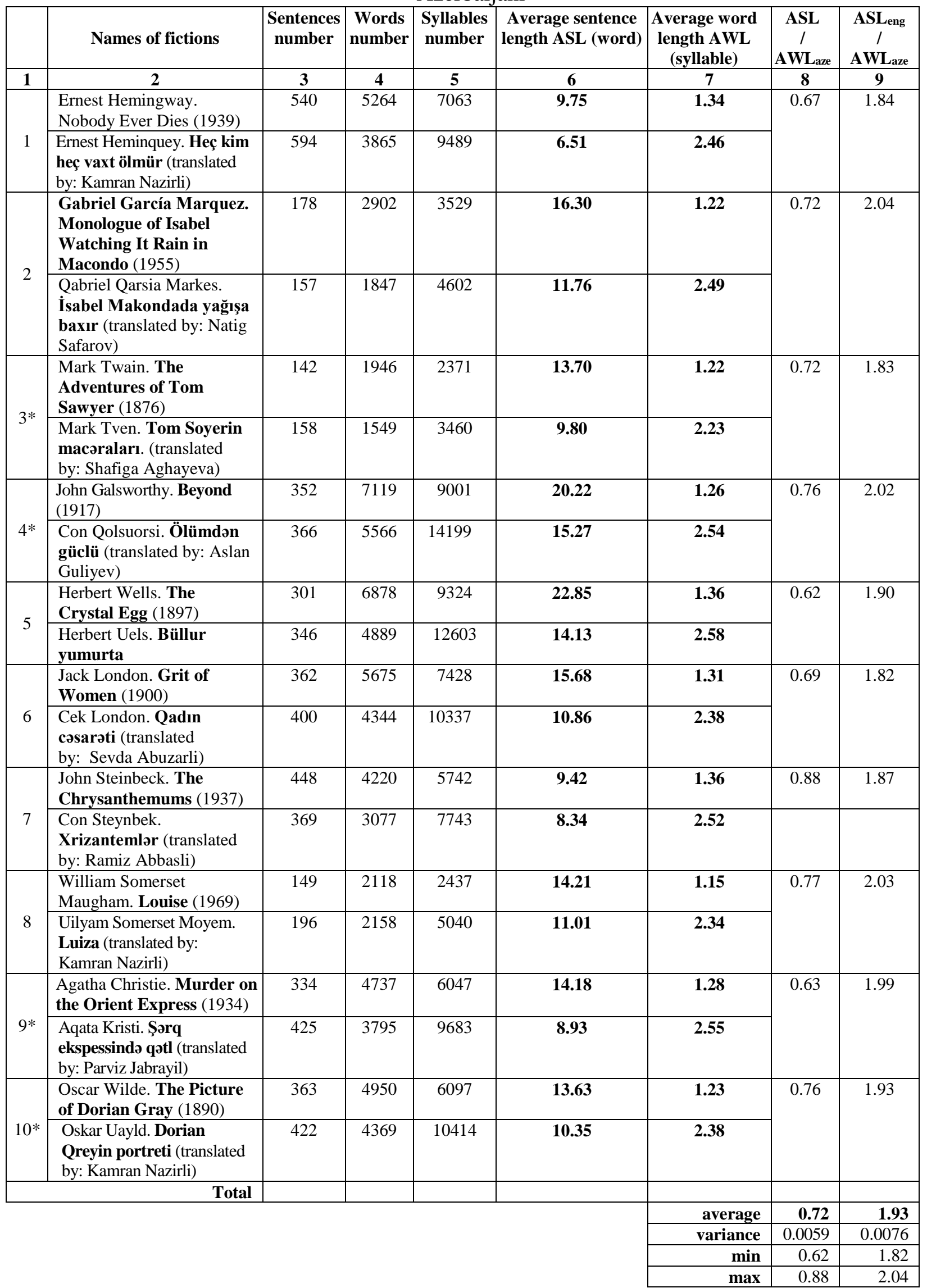


Table $6 *$

Comparison of the quantitative characteristics of the identical academic text samples in English and Azerbaijani

\begin{tabular}{|c|c|c|c|c|c|c|c|c|}
\hline & Text & $\begin{array}{c}\text { Sentences } \\
\text { number }\end{array}$ & $\begin{array}{c}\text { Words } \\
\text { number }\end{array}$ & $\begin{array}{l}\text { Syllables } \\
\text { number }\end{array}$ & \begin{tabular}{|c}
$\begin{array}{c}\text { Average sentence } \\
\text { length ASL } \\
\text { (word) }\end{array}$ \\
\end{tabular} & \begin{tabular}{|c|}
$\begin{array}{c}\text { Average word } \\
\text { length AWL } \\
\text { (syllable) }\end{array}$ \\
\end{tabular} & $\begin{array}{c}\text { ASL } \\
/ \\
\text { AWL }_{\text {aze }} \\
\end{array}$ & $\begin{array}{c}\text { ASLeng } \\
/ \\
\text { AWLaze } \\
\end{array}$ \\
\hline 1 & 2 & 3 & 4 & 5 & 6 & 7 & 8 & 9 \\
\hline \multirow{2}{*}{1} & Azerbaijan (president.az) & 40 & 840 & 1405 & 21.00 & 1.67 & \multirow[t]{2}{*}{0.82} & \multirow[t]{2}{*}{1.77} \\
\hline & Azərbaycan & 40 & 691 & 2047 & 17.28 & 2.96 & & \\
\hline \multirow{2}{*}{2} & Karabakh (president.az) & 160 & 3650 & 5812 & 22.81 & 1.59 & \multirow[t]{2}{*}{0.78} & \multirow[t]{2}{*}{1.72} \\
\hline & Qarabağ & 160 & 2844 & 7788 & 17.78 & 2.74 & & \\
\hline \multirow[t]{2}{*}{3} & $\begin{array}{l}\text { Bloody Memories } \\
\text { (president.az) }\end{array}$ & 382 & 8734 & 14542 & 22.86 & 1.66 & \multirow[t]{2}{*}{0.76} & \multirow[t]{2}{*}{1.72} \\
\hline & Qanlı yaddaş & 382 & 6595 & 18824 & 17.26 & 2.85 & & \\
\hline \multirow[t]{2}{*}{4} & $\begin{array}{l}\text { History of Military in } \\
\text { Azerbaijan (azerbaijan.az) }\end{array}$ & 90 & 2148 & 3736 & 23.87 & 1.74 & \multirow[t]{2}{*}{0.82} & \multirow[t]{2}{*}{1.63} \\
\hline & Azərbaycanın hərb tarixi & 105 & 2058 & 5816 & 19.60 & 2.83 & & \\
\hline \multirow[t]{2}{*}{5} & $\begin{array}{l}\text { Sport History in Azerbaijan } \\
\text { (azerbaijan.az) }\end{array}$ & 237 & 3949 & 6334 & 16.66 & 1.60 & \multirow[t]{2}{*}{0.88} & \multirow[t]{2}{*}{1.77} \\
\hline & Azərbaycanın idman tarixi & 235 & 3450 & 9750 & 14.68 & 2.83 & & \\
\hline \multirow[t]{2}{*}{6} & $\begin{array}{l}\text { Tourism Policy } \\
\text { (azerbaijan.az) }\end{array}$ & 91 & 2533 & 4286 & 27.84 & 1.69 & \multirow[t]{2}{*}{0.88} & \multirow[t]{2}{*}{1.77} \\
\hline & Turizm siyasəti & 86 & 2102 & 6281 & 24.44 & 2.99 & & \\
\hline \multirow{2}{*}{7} & $\begin{array}{l}\text { Nakhchivan Autonomous } \\
\text { Republic (azerbaijan.az) }\end{array}$ & 179 & 3225 & 4946 & 18.02 & $\mathbf{1 . 5 3}$ & 0.80 & 1.76 \\
\hline & $\begin{array}{l}\text { Naxçıvan Muxtar } \\
\text { Respublikası }\end{array}$ & 169 & 2441 & 6582 & 14.44 & 2.70 & & \\
\hline \multirow[t]{2}{*}{8} & $\begin{array}{l}\text { Public Health System in } \\
\text { Azerbaijan (azerbaijan.az) }\end{array}$ & 37 & 954 & 1690 & 25.78 & 1.77 & \multirow[t]{2}{*}{1.03} & \multirow[t]{2}{*}{1.76} \\
\hline & Azərbaycanda səhiyyə & 33 & 875 & 2733 & 26.52 & 3.12 & & \\
\hline \multirow[t]{2}{*}{9} & $\begin{array}{l}\text { Science of Azerbaijan } \\
\text { (azerbaijan.az) }\end{array}$ & 133 & 3045 & 5941 & 22.89 & 1.95 & \multirow[t]{2}{*}{0.88} & \multirow[t]{2}{*}{1.59} \\
\hline & Azərbaycan elmi & 130 & 2610 & 8104 & 20.08 & 3.10 & & \\
\hline \multirow[t]{4}{*}{10} & $\begin{array}{l}\text { Azerbaijani Diaspora } \\
\text { (azerbaijan.az) }\end{array}$ & 76 & 1643 & 2966 & 21.62 & 1.80 & \multirow[t]{2}{*}{1.02} & \multirow[t]{2}{*}{1.68} \\
\hline & Azərbaycan diasporu & 67 & 1482 & 4475 & 22.12 & 3.02 & & \\
\hline & & & & & & & & \\
\hline & Total & & & & & & & \\
\hline & & & & & & average & 0.87 & 1.72 \\
\hline & & & & & & variance & 0.0087 & 0.0041 \\
\hline & & & & & & $\min$ & 0.76 & 1.59 \\
\hline & & & & & & $\max$ & 1.03 & 1.77 \\
\hline
\end{tabular}

Another statistical text analysis is as follows (Table $6 * *$ ).

Table $6 * *$

Comparison of quantitative characteristics of separate sentences in English and their Azerbaijani translation

\begin{tabular}{|l|c|c|c|c|c|c|c|}
\hline \multicolumn{1}{|c|}{ Text } & $\begin{array}{c}\text { Sentences } \\
\text { number }\end{array}$ & $\begin{array}{c}\text { Words } \\
\text { number }\end{array}$ & $\begin{array}{c}\text { Syllables } \\
\text { number }\end{array}$ & $\begin{array}{c}\text { Average } \\
\text { sentence } \\
\text { length ASL } \\
\text { (word) }\end{array}$ & $\begin{array}{c}\text { Average word } \\
\text { length AWL } \\
\text { (syllable) }\end{array}$ & $\begin{array}{c}\text { ASL } \\
/ \\
\text { AWL }_{\text {aze }}\end{array}$ & $\begin{array}{c}\text { ASLeng } \\
/ \\
\text { AWL }_{\text {aze }}\end{array}$ \\
\cline { 1 - 6 } $\begin{array}{l}\text { Separate sentences in } \\
\text { English }\end{array}$ & 208 & 2312 & 2636 & $\mathbf{1 1 . 1 1}$ & $\mathbf{1 . 1 4}$ & $\mathbf{0 . 7 3}$ & $\mathbf{2 . 0 9}$ \\
\cline { 1 - 4 } \\
$\begin{array}{l}\text { Azerbaijani translations of } \\
\text { respective sentences }\end{array}$ & 208 & 1682 & 4009 & $\mathbf{8 . 0 9}$ & $\mathbf{2 . 3 8}$ & & \\
\hline
\end{tabular}




\section{Flesh formula for the texts in Azerbaijani}

If we deduct the average price for the results obtained from these three types of text (Table $6,6 *$ and $6 * *)$ :

$$
\begin{aligned}
& \frac{\text { Average number of words in sentence }(\text { English text })}{\text { Average number of words in sentence }(\text { Azerbaijani translation })}=\frac{0.72+0.87+0.73}{3}=0.77 \\
& \frac{\text { Average number of syllables in words }(\text { English text })}{\text { Average number of syllables in words }(\text { Azerbaijani translation })}=\frac{1.93+1.72+2.09}{3}=1.91
\end{aligned}
$$

Thus, in Flesch readability formula (1), the coefficient of the average sentence length $(\boldsymbol{S})$ should be corrected 0.77 times, and the coefficient of the average word length $(\boldsymbol{W})-1.91$ times. Then, the Flesch readability formula for the Azerbaijani texts will be as follows:

$$
\boldsymbol{K}=206.835-(1.318 \times \boldsymbol{S})-(44.3 \times \boldsymbol{W}),
$$

where, $\boldsymbol{K}$ is an indicator of the text readability, $\boldsymbol{S}$-average sentence length, and $\boldsymbol{W}$ average number of syllables in the word.

Next, if the readability value in different estimates of the average sentence length and the average word length is calculated by the formula (2), Table 4 will be as below (Table 7).

The readability values of the text samples of the fictions in both languages given in Table 6 are calculated and compared using the abovementioned formulas (1) and (2) (Table 8). As a result, the complexity of the original and translation texts is almost identical (correlation coefficient - 0.722).

Table 7.

\begin{tabular}{|c|c|c|c|c|c|c|c|c|c|}
\hline \multirow{12}{*}{ 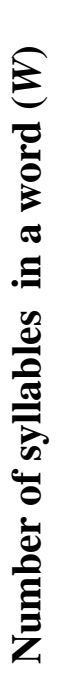 } & \multicolumn{9}{|c|}{ Number of words in a sentence $(S)$} \\
\hline & & 4 & 5 & 6 & 7 & 8 & 9 & 10 & 11 \\
\hline & 2.1 & 109 & 107 & 106 & 105 & 103 & 102 & 101 & 99 \\
\hline & 2.2 & 104 & 103 & 101 & 100 & 99 & 98 & 96 & 95 \\
\hline & 2.3 & 100 & 98 & 97 & 96 & 94 & 93 & 92 & 90 \\
\hline & 2.4 & 95 & 94 & 93 & 91 & 90 & 89 & 87 & 86 \\
\hline & 2.5 & 91 & 89 & 88 & 87 & 86 & 84 & 83 & 82 \\
\hline & 2.6 & 86 & 85 & 84 & 82 & 81 & 80 & 78 & 77 \\
\hline & 2.7 & 82 & 81 & 79 & 78 & 77 & 75 & 74 & 73 \\
\hline & 2.8 & 78 & 76 & 75 & 74 & 72 & 71 & 70 & 68 \\
\hline & 2.9 & 75 & 72 & 70 & 69 & 68 & 67 & 65 & 64 \\
\hline & 3 & 69 & 67 & 66 & 65 & 63 & 62 & 61 & 59 \\
\hline
\end{tabular}

Dependence of readability coefficient on the number of words and syllables in Flesch formula adapted for texts in Azerbaijani 
Table 8

Comparison of Flesch formula values of readability of the identical texts in

English and Azerbaijani

\begin{tabular}{|c|l|c|c|c|}
\hline & \multicolumn{1}{|c|}{ Names of fictions } & $\begin{array}{c}\text { Flesch formula } \\
\text { readability coefficient } \\
- \text { K (English) }\end{array}$ & $\begin{array}{c}\text { Flesch formula } \\
\text { readability } \\
\text { coefficient - K } \\
\text { (Azeri) }\end{array}$ & Difference \\
\hline 1. & $\begin{array}{l}\text { Ernest Hemingway. Nobody } \\
\text { Ever Dies }\end{array}$ & 84 & 89 & 5 \\
\hline 2. & $\begin{array}{l}\text { Gabriel García Marquez. } \\
\text { Monologue of Isabel } \\
\text { Watching It Rain in Macondo }\end{array}$ & 87 & 81 & 6 \\
\hline 3. & $\begin{array}{l}\text { Mark Twain. The Adventures } \\
\text { of Tom Sawyer }\end{array}$ & 90 & 95 & 5 \\
\hline 4. & John Galsworthy. Beyond & 80 & 74 & 6 \\
\hline 5. & $\begin{array}{l}\text { Herbert Wells. The Crystal } \\
\text { Egg }\end{array}$ & 69 & 74 & 7 \\
\hline 6. & Jack London. Grit of Women & 80 & 87 & 6 \\
\hline 7. & $\begin{array}{l}\text { John Steinbeck. The } \\
\text { Chrysanthemums }\end{array}$ & 82 & 89 & 2 \\
\hline 8. & $\begin{array}{l}\text { William Somerset Maugham. } \\
\text { Louise }\end{array}$ & 95 & 82 & 1 \\
\hline 9. & $\begin{array}{l}\text { Agatha Christie. Murder on } \\
\text { the Orient Express }\end{array}$ & 84 & 88 & \\
\hline 10. & $\begin{array}{l}\text { Oscar Wilde. The Picture of } \\
\text { Dorian Gray }\end{array}$ & 89 & & \\
\hline & & & & \\
\hline &
\end{tabular}

The correlation diagram of the readability of the identical texts in English and Azerbaijani is given in Figure 3.

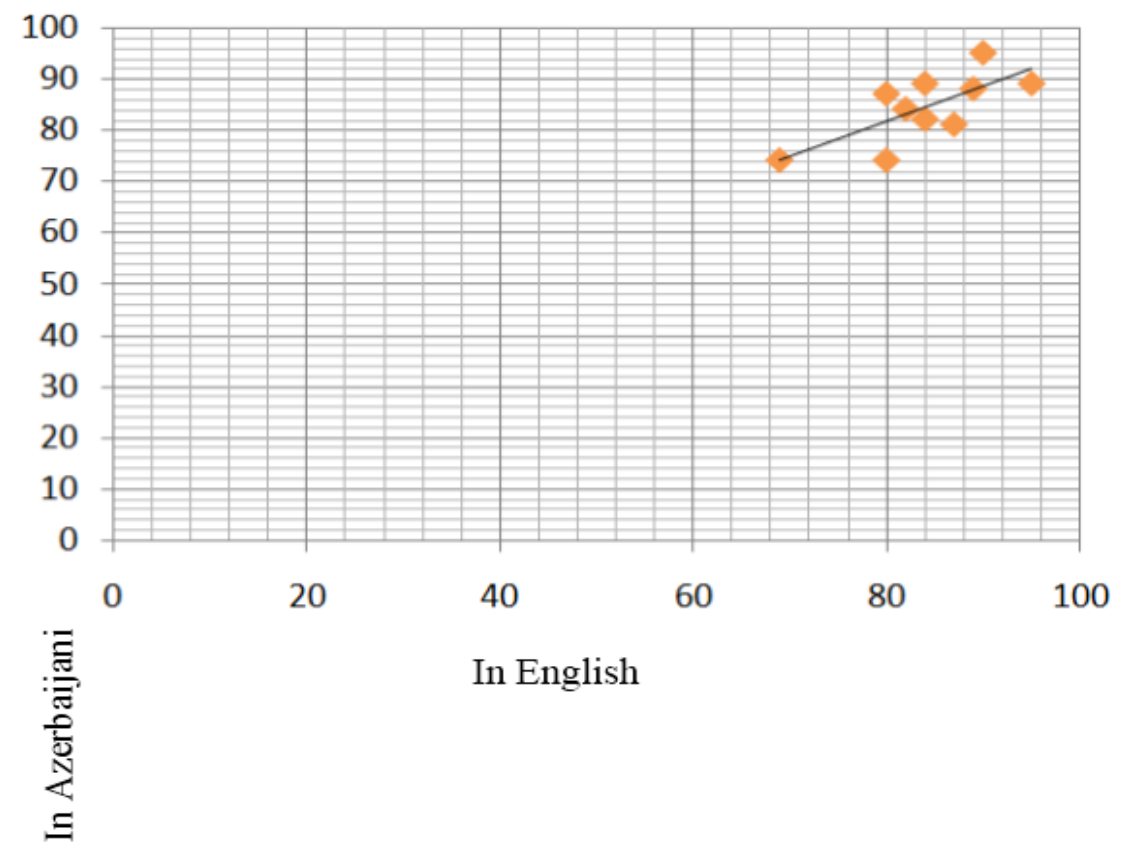

Figure 3. Readability correlation diagram of the identical texts in English and Azerbaijani 


\section{Conclusion}

Figure 3 showed that the correlation between the texts in English and the readability of their Azerbaijani translations was positive. This indicated that the coefficients in Flesch readability formula are correctly correlated. Thus, the formula (2) and Table 3 can be used to define the complexity of the texts in the Azerbaijani language.

\section{References}

1. Abdullayev A.S. The history of teaching the Azerbaijani language. Baku: Maarif, 1966.

2. Sadigov I.C. The complexity of texts and evaluation ways. Express-information. Information society series, Baku: "Information Technologies" publishing house, 2012, 72 p.

3. DuBay W.H. The Principles of Readability - Costa Mesa, California: Impact Information, 2004.

4. Klare G.R. The measurement of readability. Ames: Iowa State University Press, 1963.

5. Hargis G., Hernandez A.K., Hughes P., Ramaker J., Rouiller S., Wilde E. Developing quality technical information: A handbook for writers and editors. Upper Saddle River, NJ: Prentice Hall, 1998.

6. McLaughlin G.H. SMOG grading - a new readability formula // Journal of reading, 1969, vol.12, no.8, 639-646.

7. Dale E., Chall J.S. The concept of readability. Elementary English, 1949, 26: 23.

8. Oborneva I.V. Automation of the evaluation of the quality of text perception // Bulletin of the Moscow City Pedagogical University, 2005.

9. Muller V.K. English-Russian Dictionary, Moscow: Russian Language, 1995.

10. Explanatory dictionary of the Azerbaijani language. Four volumes, Baku: Sharg-Garb, 2006. 